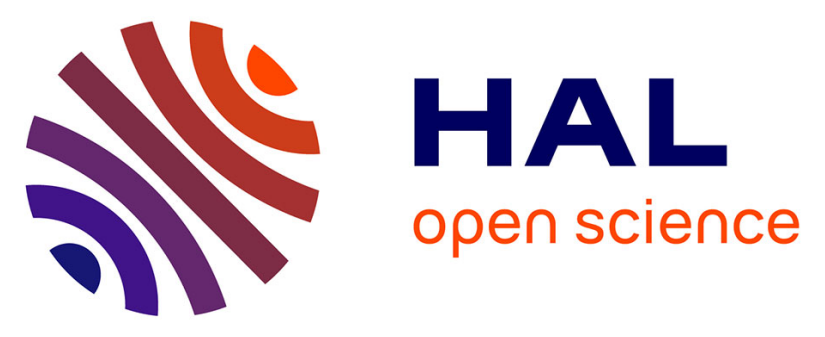

\title{
Understanding the Sn Loading Impact on the Performance of Mesoporous Carbon/Sn-Based Nanocomposites in Li-Ion Batteries
}

Cristina Nita, Julien Fullenwarth, Laure Monconduit, Jean-Marc Le Meins, Julien Parmentier, Moulay Tahar Sougrati, Camélia Matei ghimbeu

\section{To cite this version:}

Cristina Nita, Julien Fullenwarth, Laure Monconduit, Jean-Marc Le Meins, Julien Parmentier, et al.. Understanding the Sn Loading Impact on the Performance of Mesoporous Carbon/Sn-Based Nanocomposites in Li-Ion Batteries. ChemElectroChem, 2018, 5 (21), pp.3249-3257. 10.1002/celc.201800835 . hal-02464997

\section{HAL Id: hal-02464997 https://hal.science/hal-02464997}

Submitted on 6 Feb 2020

HAL is a multi-disciplinary open access archive for the deposit and dissemination of scientific research documents, whether they are published or not. The documents may come from teaching and research institutions in France or abroad, or from public or private research centers.
L'archive ouverte pluridisciplinaire HAL, est destinée au dépôt et à la diffusion de documents scientifiques de niveau recherche, publiés ou non, émanant des établissements d'enseignement et de recherche français ou étrangers, des laboratoires publics ou privés. 


\title{
Understanding the Sn loading impact on the performances of mesoporous carbon/Sn based nanocomposites in Li-ion batteries
}

\author{
Cristina Nita ${ }^{[a],[b]}$, Julien Fullenwarth ${ }^{[c],[d]}$, Laure Monconduit ${ }^{[c],[d]}$, Jean-Marc Le Meins ${ }^{[a]}$, Julien \\ Parmentier ${ }^{[a]}$, Moulay Tahar Sougrati [c],[d], Camélia Matei Ghimbeu [a],[d],
}

\begin{abstract}
Herein, we report a systematic study on the understanding of the influence of tin metal precursor salt amount on the formation of carbon/tin hybrid materials and their performances as anode in Li-ion batteries. Small Sn metallic particles $(\approx 5 \mathrm{~nm})$ covered by a $\mathrm{SnO}_{2}$ layer were uniformly dispersed in a mesoporous carbon for low loading of tin, while for higher Sn loading the formation of Sn-based particles aggregates $(\sim 200 \mathrm{~nm})$ is promoted as well. By increasing the Sn loading from 20 to $80 \%$, the irreversible capacity was successfully reduced and the reversible capacity improved. This could be mainly related to the decrease of the $\mathrm{C} / \mathrm{Sn}$ hybrids specific surface area and the increase of the Sn active species. For long term cycling, capacity fading was observed particularly for high $\mathrm{Sn}$ loadings and assigned to the Sn nanoparticles placed outside the carbon network which upon lithiation witness large volume expansion leading to severe particle growth and agglomeration. Therefore, similar reversible capacities at long cycling are reached no matter the Sn loading. For optimal electrochemical performances, it appears that a balance between the amount of $\mathrm{Sn}$ and uniform small $\mathrm{Sn}$-based particles dispersion within carbon matrix must be assured in order to design high performance anode for Li-ion batteries.
\end{abstract}

\section{Introduction}

During the last years, the interest for environmentally friendly processes and alternative sources dedicated to energy generation and storage has significantly increased. For electrical vehicles and portable electronics applications, the $\mathrm{Li}$-ion batteries have been considered the most important power

[a] Dr. C Nita, Dr. J-M Le Meins, Dr. J Parmentier, Dr. C. Matei Ghimbeu

Université de Strasbourg, Université de Haute-Alsace, Institut de Science des Matériaux de Mulhouse, UMR 7361, CNRS Address : 15 rue Jean Starcky, BP 2488, 68057 Mulhouse Cedex, France

E-mail: camelia.ghimbeu@uha.fr

[b] Dr. C Nita

Center for Advanced Laser Technologies (CETAL), National Institute for Lasers, Plasma and Radiation Physics, Atomistilor 409 bis, RO-77125, Magurele, Romania

[c] J Fullenwarth, Dr. L Monconduit, Dr. M T Sougrati

CG/AIME (UMR 5253 CNRS), Université Montpellier II CC 15-02

Place E. Bataillon, 34095 Montpellier Cedex, France

[d] J Fullenwarth, Dr. L Monconduit, Dr. M T Sougrati, Dr. C Matei Ghimbeu

Réseau sur le Stockage Electrochimique de l'Energie (RS2E) CNRS FR3459

33 Rue Saint Leu, 80039 Amiens Cedex, France

Supporting information for this article is given via a link at the end of the document. sources due to their high energy density, operating voltages and lightweight design [1]. However, the fast development of the technology demands high performing batteries, but in the same time safety and low-cost.

A Li-ion battery contains several components, each of these contributing in different ways to the improvement of the battery performances, the anode inducing a significant impact [2] Nowadays, graphite is the most used anode in Li-ion batteries, with a theoretical capacity limited to $372 \mathrm{mAh} \mathrm{g}^{-1}$, because of the limited Li storage capacity (one Li atom for six carbon atoms) ${ }^{[3]}$. In order to improve the capacity as compared to graphite an increasing interest was focused on other anode materials. For such purposes, the Sn or Sn-based materials have been considered among the best candidates, especially due their higher theoretical capacity (781 $\mathrm{mAh} \mathrm{g}^{-1}$ for $\mathrm{SnO}_{2}{ }^{[4]}$ and 990 $\mathrm{mAh} \mathrm{g}^{-1}$ for $\mathrm{Sn}{ }^{[5]}$ ). However, such metals suffer an important volume expansion during lithiation step and therefore, particles agglomeration and electrode pulverization occurs along with the loss of electrochemical performances. These drawbacks could be overcome by downsizing the Sn particle size ${ }^{[6]}$ and by using different carbon materials (carbon nanotubes ${ }^{[7]},[8]$, carbon fibers [9], carbon nanospheres [10], graphenes [11], graphite [12], mesoporous carbon [3],[13]) as supports for Sn-based hybrid materials. This allow to alleviate the macroscopic volume expansion of the composite material and, in the same time, increase its electrical conductivity and provide efficient pathways for electrolyte diffusion as demonstrated by several works [14], [15] [16] [17].

Wu et al. ${ }^{[18]}$ reported the preparation of $\mathrm{SnO}_{2}$-CNTs using glucose through a hydrothermal approach, followed by a carbonization at $500^{\circ} \mathrm{C}$ in nitrogen atmosphere. The materials present a discharge capacity of $400 \mathrm{mAh} \mathrm{g}^{-1}$ at current density of $100 \mathrm{mAg}^{-1}$, after 50 cycles, slightly higher than that of graphite, but lower than the theoretical capacity of the composite because of the solid-electrolyte interphase (SEI) formation. Cui et al. ${ }^{[17]}$ reported the preparation of Sn/onion-like carbon nanocapsules by arc discharge method with a reversible capacity of $585 \mathrm{mAh}$ $\mathrm{g}^{-1}$ after 100 cycles at very low current rate, $100 \mathrm{~mA} \mathrm{~g}^{-1}$, while Han et al. ${ }^{[16]}$ succeeded to increase the capacity up to $902 \mathrm{mAh}$ $\mathrm{g}^{-1}$ (at $100 \mathrm{~mA} \mathrm{~g}^{-1}$ after 1000 cycles) by introducing nitrogen (N) atoms in the carbon framework. The high capacity and the stable cycling could be promoted by the very low current rate used. Another limitation is the complexity of the synthesis procedure which involves specific pressure and temperature conditions. Guo et al. ${ }^{[10]}$ prepared Sn nanoparticles embedded in $\mathrm{N}$-doped hollow nanosphere which delivered $500 \mathrm{mAh} \mathrm{g}^{-1}$ at $5 \mathrm{C}$ after 500 cycles. Nano size tin particles embedded in porous multichannel carbon microtubes were synthesized by electrospinning and provided a capacity of $350 \mathrm{mAh} \mathrm{g}^{-1}$, at $2 \mathrm{C}$ rate after 600 cycles ${ }^{[19]}$. Liu et al. ${ }^{[20]}$ repported capacities up to $520 \mathrm{mAh} \mathrm{g}^{-1}$ at $500 \mathrm{~mA} \mathrm{~g}{ }^{-1}$, after 1000 cycles, for Sn/N-doped carbon nanospherers prepared by arc discharge method. Jahel et al. ${ }^{[21]},{ }^{[3]}$ pointed out that the confinement of electrochemically active $\mathrm{SnO}_{2}$ nanoparticles (ca. $2 \mathrm{~nm}$ in diameter) in the pores of a mesoporous carbon is the key parameter to avoid the particle growth and agglomeration, affording high capacity and long 
stable cycling life (up to 2000 cycles). The improvement of the $\mathrm{C} / \mathrm{SnO}_{2}$ anode materials performances was achieved, with a reversible charge capacity up to $443 \mathrm{mAh} \mathrm{g}^{-1}$ at $1 \mathrm{C}$ current rate after 2000 cycles. However, the irreversible capacity of the first charge-discharge cycle was still high, the later one remaining still an important problem of such materials and is mainly related to several factors as enumerate next: (i) solid electrolyte formation due to the reactions of the electrolyte with the high surface area of the porous carbon support, ii) the electrolyte consumption due to the reduction of tin oxide species to Sn metallic phase, according to the reaction described in ${ }^{[3]}$ and iii) the small amount of active phase $\left(40 \mathrm{wt} . \% \mathrm{SnO}_{2}\right.$, corresponding to $31 \mathrm{wt} . \% \mathrm{Sn}$ ) in the composite, and therefore, the high amount of carbon (with a low electrochemical activity after the first discharge).

In order to overcome these drawbacks, the present study aims to systematically investigate the influence of Sn-based nanoparticles loading on the irreversible capacity, the reversible capacity and the cycle stability of carbon/Sn hybrids. As far as we know and highlighted by the literature review gathered in Table 1, no systematic study have been performed until now for $\mathrm{Sn} / \mathrm{C}$ hybrids to evaluate how the $\mathrm{Sn} / \mathrm{SnO}_{2}$ loadings can influence the formation of $\mathrm{Sn} / \mathrm{C}$ hybrid materials (particle size, surface chemistry and porosity) and further impact their electrochemical performances in $\mathrm{Li}$-ion batteries. In addition, the contribution of each component (carbon and Sn) to the irreversible/reversible capacity and the long term cycling is not addressed either to our knowledge. The improvement of irreversible and reversible capacity in the first cycles compared to the commercial graphite anode by adding high amounts of Sn, as well as the capacity fading behavior with further cycling is discussed in the light of material characteristics (nanoparticle dispersion/confinement in the carbon mesopores, amount of $\mathrm{SnO}_{2}$ present in the nanoparticles and specific surface area).

Table 1. Carbon/Sn-based materials for lithium-ion battery.

\begin{tabular}{|c|c|c|c|c|c|}
\hline \multirow[t]{2}{*}{$\begin{array}{l}\text { Carbonaceous } \\
\text { /Sn-based } \\
\text { material }\end{array}$} & \multirow[t]{2}{*}{$\begin{array}{c}\text { Preparation } \\
\text { method } \\
\text { of composite }\end{array}$} & \multicolumn{3}{|c|}{$\begin{array}{c}\text { Electrochemical } \\
\text { performances } \\
\text { vs. Li }\end{array}$} & \multirow[t]{2}{*}{ Refs } \\
\hline & & $\begin{array}{c}\text { Curren } \\
t \\
\text { density } \\
\left(\mathrm{mAg}^{-1}\right)\end{array}$ & $\begin{array}{c}\text { Rever } \\
\text { sible } \\
\text { capac } \\
\text { ity } \\
(\mathrm{mAh} \\
\left.\mathrm{g}^{-1}\right)\end{array}$ & $\begin{array}{c}\text { Cycle } \\
\text { s } \\
\text { numb } \\
\text { er }\end{array}$ & \\
\hline $\begin{array}{c}\text { Onion-like } \\
\text { carbon NCs/Sn } \\
\text { NPs }\end{array}$ & $\begin{array}{c}\text { Arc-discharge } \\
\text { method }\end{array}$ & 100 & 585 & 100 & {$[17]$} \\
\hline $\begin{array}{c}\text { Sn } \\
\text { nanocapsules/ } \\
\text { N-doped onion- } \\
\text { like carbon }\end{array}$ & $\begin{array}{c}\text { Arc-discharge } \\
\text { method }\end{array}$ & 100 & 902 & 1000 & {$[16]$} \\
\hline $\begin{array}{c}\text { Sn } \\
\text { nanowires/Car } \\
\text { bon nanotubes }\end{array}$ & $\begin{array}{l}\text { Chemical } \\
\text { vapor } \\
\text { deposition } \\
\text { (CVD) }\end{array}$ & 100 & $\begin{array}{l}420- \\
630\end{array}$ & 30 & [8] \\
\hline $\begin{array}{l}\text { Sn/Carbon } \\
\text { core-shell }\end{array}$ & $\begin{array}{l}\text { Hydrothermal } \\
\text { method, Heat } \\
\text { treatment }\end{array}$ & 100 & 400 & 50 & [22] \\
\hline $\begin{array}{c}\text { Sn } \\
\text { nanoparticles/N } \\
\text {-doped hollow } \\
\text { nanosphere }\end{array}$ & $\begin{array}{c}\text { Solvothermal } \\
\text { method }\end{array}$ & $0.2 \mathrm{C}$ & 1070 & 500 & {$[10]$} \\
\hline
\end{tabular}

\begin{tabular}{|c|c|c|c|c|c|}
\hline $\begin{array}{l}\text { Sn/carbon } \\
\text { nanotubes } \\
\text { composite }\end{array}$ & $\begin{array}{l}\text { Acid-etching } \\
\text { treatment }\end{array}$ & 30 & 413 & 100 & [15] \\
\hline $\begin{array}{c}\text { Sn NPs/Carbon } \\
\text { nanotubes } \\
\text { nanocapsules }\end{array}$ & $\begin{array}{l}\text { Direct current } \\
\text { (DC) arc- } \\
\text { discharge } \\
\text { method }\end{array}$ & 100 & 600 & 10 & {$[14]$} \\
\hline $\begin{array}{c}\mathrm{SnO}_{2} \\
\text { nanocrystals/ } \\
\text { carbon } \\
\text { nanotubes }\end{array}$ & $\begin{array}{c}\text { Solvothermal } \\
\text { method }\end{array}$ & 200 & 497 & 300 & [23] \\
\hline $\begin{array}{c}\mathrm{SnO}_{2} / \text { carbon } \\
\text { nanotubes }\end{array}$ & $\begin{array}{c}\text { Solvothermal } \\
\text { method }\end{array}$ & 100 & 709 & 100 & {$[7]$} \\
\hline $\begin{array}{c}\mathrm{SnO}_{2} / \text { Carbon } \\
\text { nanotubes }\end{array}$ & $\begin{array}{c}\text { Hydrothermal } \\
\text { approach }\end{array}$ & 100 & 400 & 50 & {$[18]$} \\
\hline $\begin{array}{c}\text { Sn/N-doped } \\
\text { carbon } \\
\text { nanospherers }\end{array}$ & $\begin{array}{l}\text { Arc-discharge } \\
\text { method }\end{array}$ & 500 & 520 & 1000 & [20] \\
\hline $\begin{array}{c}\text { Sn NPs/ } \\
\text { carbon } \\
\text { microtubes }\end{array}$ & $\begin{array}{c}\text { Electrospinnin } \\
\mathrm{g}, \\
\text { carbonization }\end{array}$ & $2 C$ & 350 & 600 & [19] \\
\hline $\begin{array}{l}\text { Sn particles/ } \\
\text { Carbon fibers }\end{array}$ & $\begin{array}{l}\text { Impregnation/ } \\
\text { heat treatment }\end{array}$ & $0.1 \mathrm{C}$ & 740 & 160 & [9] \\
\hline Sn/graphite & $\begin{array}{c}\text { Electrocatalysi } \\
\mathrm{s}\end{array}$ & $\mathrm{C} / 15$ & 433 & 35 & [12] \\
\hline $\begin{array}{l}\text { Sn NPs } \\
\text { /carbon/ } \\
\text { graphene }\end{array}$ & $\begin{array}{c}\text { Hydrothermal } \\
\text { process }\end{array}$ & 100 & 662 & 100 & [11] \\
\hline $\begin{array}{c}\text { Sn/carbon } \\
\text { nanocomposite }\end{array}$ & $\begin{array}{c}\text { Sol-gel } \\
\text { carbothermal } \\
\text { reduction }\end{array}$ & 20 & 588 & 200 & [5] \\
\hline $\begin{array}{c}\text { Sn/porous } \\
\text { carbon }\end{array}$ & & 100 & 788 & 300 & [24] \\
\hline $\begin{array}{c}\mathrm{Sn} / \\
\text { mesoporous } \\
\text { carbon }\end{array}$ & $\begin{array}{c}\text { Sol-gel } \\
\text { polymerization }\end{array}$ & 20 & 400 & 15 & [13] \\
\hline \multirow[t]{2}{*}{$\begin{array}{c}\mathrm{SnO}_{2} / \text { Mesopor } \\
\text { ous carbon }\end{array}$} & \multirow[t]{2}{*}{$\begin{array}{c}\text { Impregnation } \\
\text { Heat } \\
\text { Treatments }\end{array}$} & $1 \mathrm{C}$ & 511 & 500 & [3] \\
\hline & & 200 & 367 & 2000 & \\
\hline
\end{tabular}

\section{Results and Discussion}

\section{Material characterization}

Mesoporous carbon materials with embedded Sn nanoparticles were synthesized and characterized in order to study the influence of $\mathrm{Sn}$ loading on the $\mathrm{C} / \mathrm{Sn}$ hybrid material characteristics and performances. The idea of using carbons with tunable pore size was motivated by our previous work [3], [21] where we have shown that the confinement of $\mathrm{small}^{\mathrm{SnO}_{2}}$ nanoparticles inside the pores is the key parameter to avoid NPs agglomeration and to ensure long and stable cycle life in the battery. 
The XRD pattern of mesoporous carbon exhibits three diffraction peaks, corresponding to the hexagonal graphite structure (Figure S1a, Supporting Information). The presence of broad peaks indicates a low degree of graphitization. SAXS patterns (Figure S1b, Supporting Information) display an intense peak at $0.97^{\circ}$ ( 2 theta) sign of the presence of a mesoporous structure which is confirmed by TEM images reveling a wormlike structure with mesopores having relatively uniform size (Figure S1c, Supporting Information).

For C/Sn hybrid materials, the XRD patterns exhibit several intense peaks which were all indexed to the tetragonal Sn phase (pdf 00-004-0673) (Figure 1). A small quantity of $\mathrm{SnO}_{2}$ is also formed as evidenced by the small and large (211) peak at $51^{\circ}$ (2theta), noted ${ }^{[19]}$. This oxide is probably present as a layer formed around the Sn nanoparticles and it could be formed during the "exposure" of the sample in air, since it is well known that smaller the nanoparticles are, easier their oxidization is ${ }^{[25}$ but also can be due to incomplete reduction of the Sn-based precursor. The nature and amount of such oxide layer is worth to be investigated in more detail since it is electrochemically active in the battery and contributes to the active mass of the samples.

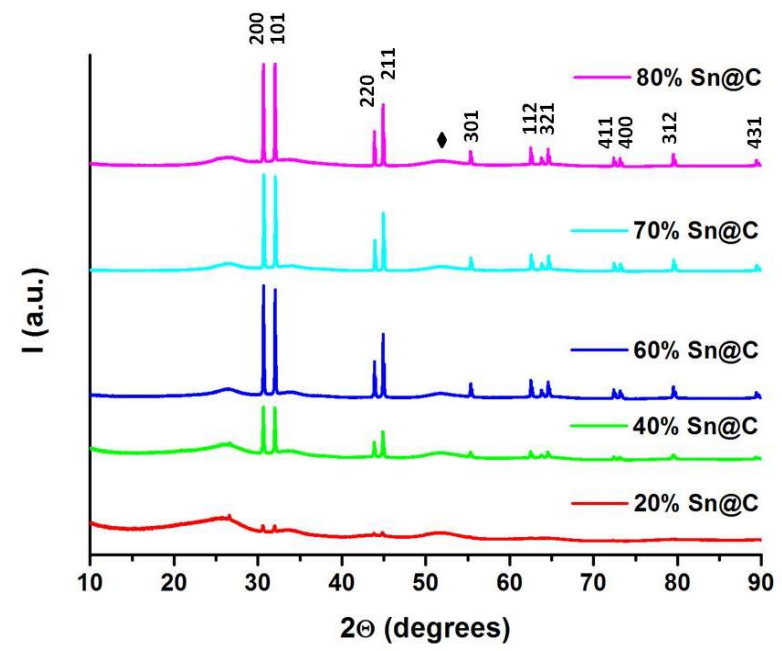

Figure 1. $\mathrm{XRD}$ patterns for $\mathrm{C} / \mathrm{S} n$ hybrid materials with different $\mathrm{Sn}$ loading ( $\mathrm{x} \%$ Sn@C, x=20/40/60/70/80).

If the structure of the materials was not changed by varying Sn loading, the size of the Sn crystallites seems to be significant influenced. Particle size information was extracted by two complementary experiments: TEM and powder XRD. For this last one, the crystallite sizes which are related to size of domains over which diffraction is coherent (later called "apparent size") were extracted from the FWHM (full width at half maximum) of individual diffraction line profile via WinPlotr [26], DIFFRAC.EVA ${ }^{[27]}$ and then using the Scherrer formula ${ }^{[28]}$. Main objective is to obtain a trend for the same family of compounds. Instrumental resolution function of the diffractometer was taken into account for the calculation because of the rather low FWHM values but let us keep in mind the limitation of the method according to the different hypothesis it involves (Gaussian peak profiles, size distribution not too large, etc...). The selected Sn reflection for this study is (200) which is the most intense, not too affected by asymmetric profile and with no peak overlap. Anisotropic line broadening is not observed for all these hybrid materials. This study allows to see the variation of the apparent size of the Sn crystallites as a function of the Sn loading (Table 2). For materials with different $\mathrm{Sn}$ loading, the apparent crystallite size increases with the Sn content from $67 \mathrm{~nm}$ for 20 wt.\% of Sn to $148 \mathrm{~nm}$ for $80 \mathrm{wt} . \%$ of Sn. This tendency is in agreement with Oswald ripening mechanisms and in line with our previous work ${ }^{[29],[30]}$.
Insights in the structure and morphology of the different materials were assessed by STEM (Figure 2). All the composites display small particles, uniformly distributed in the carbon matrix, but also bigger particles are present as aggregates. The HRTEM images allow to estimate a size of primary particles of about $\sim 5 \mathrm{~nm}$ (Figure S2e, Supporting Informations). The homogeneous distribution of the smallest particles suggest that the wet impregnation/reduction protocols allow a good diffusion of $\mathrm{Sn}^{4+}$ and $\mathrm{BH}_{4}$ species in the porous carbon framework. Few aggregates with diameters ranging between 50 to $200 \mathrm{~nm}$ can be distinguished, especially for materials with high Sn loading (70\%Sn@C and 80\%Sn@C). For the larger particles, their size increases with the loading as shown previously [29],[30] and also observed by XRD microstructural analysis (Table 2). The large size of the agglomerated particles justifies also the high and very sharp XRD peaks (Figure 1)

In addition to TEM, the energy dispersive X-ray (EDX) mapping of the $\mathrm{C} / \mathrm{Sn}$-based materials confirms the uniform dispersion of $\mathrm{Sn}$ in the carbon support as well as the presence of aggregates (Figure S2, Supporting Information).
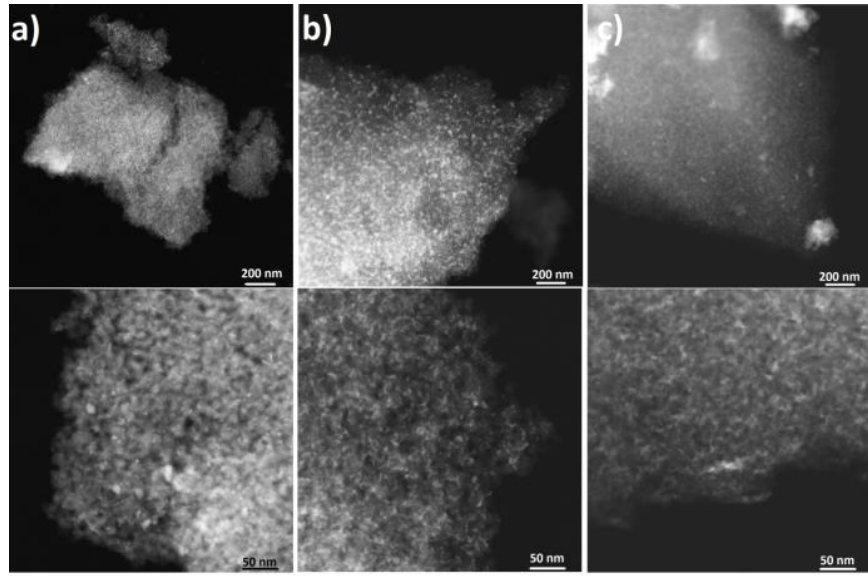

Figure 2. STEM images for carbon/Sn-based hybrid materials having different loadings corresponding to 20 wt.\% Sn (a), 60 wt.\% Sn (b); 80 wt.\% Sn (c).

The most encountered problem, and rarely evaluated in the literature was related to the quantification of the $\mathrm{Sn}$ particles loading in the carbon framework and usually this problem is not addressed in many works. By considering the XRD results, it was demonstrated that the materials contains carbon, metallic $\mathrm{Sn}$ and $\mathrm{SnO}_{2}$. The composition and thermal/chemical stability of $\mathrm{C} / \mathrm{Sn}$-based hybrid materials were determined by TGA in air (Figure S3a, Supporting Information), which allows the combustion of carbon and determination of final $\mathrm{SnO}_{2}$ quantity, coming both from the initial $\mathrm{SnO}_{2}$ content, but also from the oxidation of metallic Sn during TGA under air (Table 2). The amounts of $\mathrm{SnO}_{2}$ obtained varies between 14 and 89 wt.\%. However, only the TGA results do not allow to discriminate between the initial $\mathrm{Sn}$ and $\mathrm{SnO}_{2}$ in the hybrid materials Therefore, complementary experiments to determine $\mathrm{Sn} / \mathrm{SnO}_{2}$ ratios of the materials were performed by Mössbauer spectroscopy (Figure 3, Table 2). 


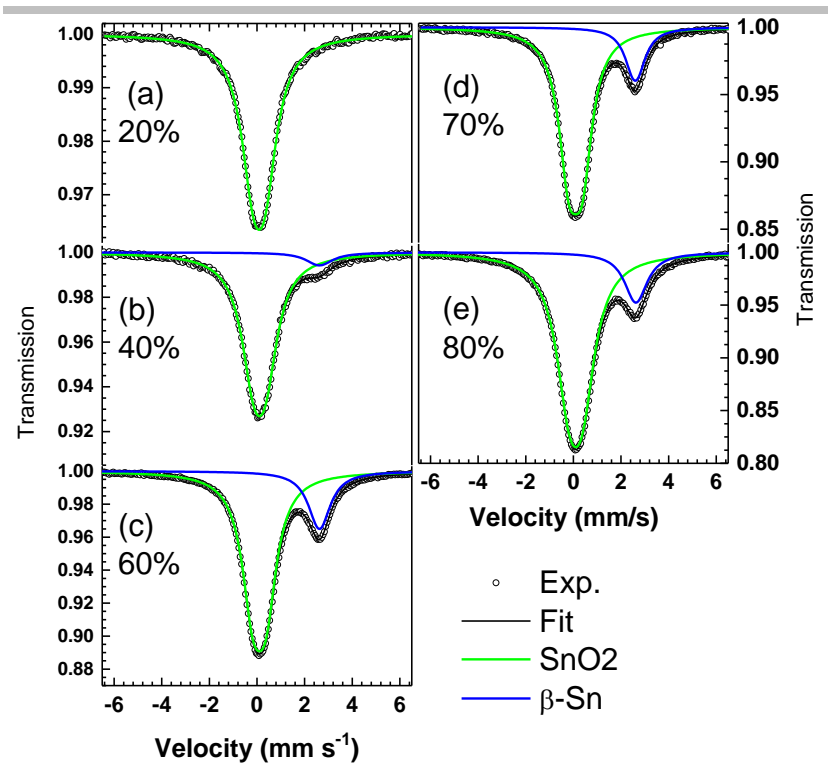

Figure 3. Room temperature Mössbauer spectra for carbon/Sn-based materials having different Sn loadings X\%Sn@C (x=20/40/60/70/80).

Spectra obtained with different Sn loadings and carbon supports were fitted with 2 unresolved doublets corresponding to $\mathrm{SnO}_{2}$ (green) and metallic tin (blue). $\mathrm{SnO}_{2}$ has an isomer shift of $0.0-0.01 \mathrm{~mm} / \mathrm{s}$ and a quadrupole splitting of $0.51-0.57 \mathrm{~mm} / \mathrm{s}$, while tetragonal $\mathrm{Sn}(\beta-\mathrm{Sn})$ has an isomer shift of $2.51-2.53 \mathrm{~mm}$ $\mathrm{s}^{-1}$ and a quadrupole splitting of $0.14-0.26 \mathrm{~mm} \mathrm{~s}^{-1}$. The results confirm the presence of both compounds: $\mathrm{Sn}$ and $\mathrm{SnO}_{2}$. The $\mathrm{Sn} / \mathrm{SnO}_{2}$ ratio measured by Mössbauer spectroscopy increases in the increase of $\mathrm{Sn}$ loading in the composite (ratio from $31.6 / 68.4$ to $60.5 / 39.5 \mathrm{Sn} / \mathrm{SnO}_{2}$ for $\mathrm{Sn}$ loading ranging from $40 \%$ to $60 \%$ wt, Table 2). For high loadings (samples with 70 and 80 wt.\% Sn), increase of the Sn loading does not induce a significant evolution of the $\mathrm{Sn} / \mathrm{SnO}_{2}$ ratios.

The amount of formed $\mathrm{SnO}_{2}$ may be explained by two factors, i.e, the particle size and particle location in the carbon network. On one hand, the Sn crystallites size increases from 67 $\mathrm{nm}$ to $148 \mathrm{~nm}$ (Table 2) when increasing the loading from 20 to $80 \%$ and the oxidation tendency generally increases with the decrease of the particle/crystallite size ${ }^{[25],[31]}$. However, starting with $60 \%$ of loading, a slight increase of $\mathrm{SnO}_{2}$ amount is observed (Table 2) and this may be probably related to the higher amount of agglomerated Sn particles situated on the carbon surface, therefore, not confined in carbon pores (Figure 2) and more exposed to oxidation.

For $20 \%$ Sn@C sample, the metallic Sn quantity is so low (limit of detection) that it can hardly be detected by Mössbauer, especially because of the Lamb-Mössbauer factor which is ten times smaller for $\mathrm{Sn}$ than for $\mathrm{SnO}_{2}{ }^{[32]}$. So, for the future calculations and experiments it will be assumed that the $20 \% \mathrm{Sn} @ \mathrm{C}$ sample contains only $\mathrm{SnO}_{2}$.

Based on Mössbauer results which provided the $\mathrm{Sn}$ to $\mathrm{SnO}_{2}$ ratio in each composite, the amounts of $\mathrm{Sn}$ and $\mathrm{SnO}_{2}$ could be determined taking into consideration the TGA results and further used to correctly asses the electrochemical performances (Table 2).
Table 2. Crystallite size determined by $\mathrm{XRD}$ and quantification of $\mathrm{Sn}$ and $\mathrm{SnO}_{2}$ amounts contained in the $\mathrm{Sn} / \mathrm{C}$ materials, based on Mössbauer spectroscopy and TGA analysis.

\begin{tabular}{|c|c|c|c|c|c|c|}
\hline \multirow[t]{2}{*}{ Material } & \multirow[t]{2}{*}{ 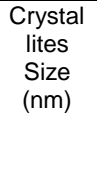 } & \multicolumn{2}{|c|}{$\begin{array}{c}\mathrm{Sn} \text { and } \mathrm{SnO}_{2} \\
\text { relative quantities } \\
\text { by Mössbauer } \\
(\%)\end{array}$} & \multirow{2}{*}{$\begin{array}{r}\mathrm{SnO}_{2} \\
\text { by TGA } \\
\text { (wt.\%) } \\
\end{array}$} & \multicolumn{2}{|c|}{$\begin{array}{c}\text { Initial quantities } \\
\text { by TGA and } \\
\text { Mössbauer } \\
\text { (wt. \%) }\end{array}$} \\
\hline & & $\begin{array}{c}\mathrm{SnO}_{2} \\
(\mathrm{Sn}(\mathrm{IV}))\end{array}$ & $\begin{array}{c}\mathrm{Sn} \\
(\beta-\mathrm{Sn})\end{array}$ & & $\mathrm{SnO}_{2}$ & Sn \\
\hline 20\%Sn@C & 67 & 100 & 0 & 14 & 14 & 0 \\
\hline 40\%Sn@C & 78 & 68.4 & 31.6 & 21 & 14.4 & 6.6 \\
\hline 60\%Sn@C & 107 & 39.6 & 60.4 & 56 & 22.1 & 33.7 \\
\hline 70\%Sn@C & 110 & 44.8 & 55.2 & 66 & 29.7 & 36.6 \\
\hline 80\%Sn@C & 148 & 46.9 & 53.1 & 89 & 41.7 & 47.3 \\
\hline
\end{tabular}

The composition and chemical oxidation state of $\mathrm{Sn}$ on the surface of the materials ( $<10 \mathrm{~nm}$ thickness) were determined by XPS measurements (Figure S3b, Supporting Information and Table 3). Thus, the C1s, O1s and Sn3d peaks were detected. For all materials, two peaks are observed on the Sn 3d spectra and the separation binding energy between them is always 8.4 $\mathrm{eV}$, which is in good agreement with the energy splitting of $\mathrm{Sn}$ and $\mathrm{SnO}_{2}{ }^{\text {[21] }}$. The shift of the peak positions for $20 \% \mathrm{Sn} @ \mathrm{C}$ material could be induced by the high amount of $\mathrm{SnO}_{2}$, confirmed also by Mössbauer spectroscopy (Table 2), which is less conductive than the metallic Sn. The Sn amount increases by increasing the loading from 26.7 wt. $\%$ for $20 \%$ Sn@C to 72.1 wt.\% for 80\%Sn@C, while the atomic ratio O/Sn is comprised between 1.66 and 1.9 which confirms the presence of a $\mathrm{SnO}_{2}$ layer in the surface of the material (Table 3 ).

The textural properties of the carbon and composite materials (specific surface area, porous volume and pore size) were evaluated by $\mathrm{N}_{2}$ physisorption technique $(77 \mathrm{~K})$. A mixture of type I/IV isotherms characteristic to micro/mesoporous materials [3] were observed in all cases (Figure 4a). The low relative pressure up-takes evidence the presence of micropores (size $<2 \mathrm{~nm})$. The microporous volume $\left(\mathrm{V}_{\text {micro }}\right)$ of the carbon support is about $0.28 \mathrm{~cm}^{3} \mathrm{~g}^{-1}$, with a high BET specific surface area (SSA) of $665 \mathrm{~m}^{2} \mathrm{~g}^{-1}$ (Table 4).

Table 3. The chemical composition of the carbon/Sn-based materials obtained by XPS analysis.

\begin{tabular}{ccccccc}
\hline Material & \multicolumn{3}{c}{ Composition, wt \% } & \multicolumn{3}{c}{ Repartition of oxygen, wt\% } \\
\cline { 2 - 7 } & $\mathrm{C}$ & $\mathrm{Sn}$ & $\mathrm{O}$ & $\mathrm{O}-(\mathrm{C})$ & $\mathrm{O}-(\mathrm{Sn})$ & $\mathrm{O}-(\mathrm{Sn}) / \mathrm{Sn}$ \\
\hline 20\%Sn@C & 61.8 & 26.7 & 11.5 & 4.7 & 6.8 & 1.90 \\
40\%Sn@C & 45.3 & 41.2 & 13.5 & 3.1 & 10.4 & 1.88 \\
$60 \% \mathrm{Sn} @ \mathrm{C}$ & 11.8 & 69.9 & 18.2 & 2.6 & 15.6 & 1.66 \\
$80 \% \mathrm{Sn} @ \mathrm{C}$ & 8.8 & 72.1 & 19.2 & 2.7 & 16.5 & 1.69 \\
\hline
\end{tabular}

The total porous volume $\left(\mathrm{V}_{\mathrm{T}}\right)$ for carbon is $0.97 \mathrm{~cm}^{3} \mathrm{~g}^{-1}$, indicating a mesoporosity size of $0.69 \mathrm{~cm}^{3} \mathrm{~g}^{-1}$ which could allow the accomodation of the Sn-based nanoparticles. The Sn addition induces a decrease of the $N_{2}$ adsorbed volume proportional with the Sn loading (Figure 4a). The evolution of the porous volume and SSA with the Sn loading are presented in the Figure 4c, $d$ and Table 4. The $V_{\text {micro }}$ decreases from 0.21 $\mathrm{cm}^{3} \mathrm{~g}^{-1}$ for $20 \% \mathrm{Sn} @ \mathrm{C}$ to $0.07 \mathrm{~cm}^{3} \mathrm{~g}^{-1}$ for $80 \% \mathrm{Sn} @ \mathrm{C}$, while the SSA go down to $181 \mathrm{~m}^{2} \mathrm{~g}^{-1}$. The $\mathrm{V}_{\mathrm{T}}$ presents the same decreasing trend from $0.79 \mathrm{~cm}^{3} \mathrm{~g}^{-1}$ for $20 \% \mathrm{Sn} @ \mathrm{C}$ to $0.17 \mathrm{~cm}^{3} \mathrm{~g}^{-1}$ for $80 \% \mathrm{Sn@C}$, inducing the same behavior for the $\mathrm{V}_{\text {meso }}$ values. 
As can be noticed (Fig. 4c), the mesoporous volume decrease more than microporous volume when increasing the Sn loading, suggesting a more preferential location of the particles in larger pore. This is rather related to the size of the Sn particle $\sim 5 \mathrm{~nm}$ which can be better accommodated in moesopores having sizes of about $8 \mathrm{~nm}$ as will be discuss latter than in micropore having size $<1 \mathrm{~nm}$.

The pore size distribution (PSD) was obtained from the adsorption branch of the $\mathrm{N}_{2}$ isotherms using 2D NLDFT model. The results show the presence of two types of pores: micropores $(\sim 0.8 \mathrm{~nm})$ and mesopores $(\sim 8 \mathrm{~nm})$ (Figure $4 \mathrm{~b})$. In contrast with the SSA and porous volumes, the pore size distribution before and after $\mathrm{Sn} / \mathrm{SnO}_{2}$ impregnation remains constant no matter the Sn loading. The presence of both types of pore are important, since they allow the diffusion of the electrolyte through the material and particularly the larger pores may accommodate the $\mathrm{Sn}$ particles and avoid their expansion/agglomeration during cycling.

Therefore, the incorporation of the $\mathrm{Sn} / \mathrm{SnO}_{2}$ nanoparticles induces a decrease in the surface area and porous volume. This may be explained mainly by two factors: i) higher density of metallic Sn-based particles than carbon, ii) confinement of the particles in the carbon pores (pore blockage with the particles). To discriminate between these two effects, the textural values were calculated per gram of carbon based on $\mathrm{Sn}$ and $\mathrm{SnO}_{2}$ contents determined in Table 2. For low loadings ranging from 20 to $40 \%$, the SSA and porous volume calculated per gram of carbon are similar to that of pristine carbon $(\mathrm{C})$, while for high loadings i.e., 60 to $80 \%$, surprisingly these values gradually increases (Figure 4d). Two hypotheses may be proposed for this behavior: modification of carbon during the $\mathrm{Sn}^{4+}$ infiltration/reduction/drying steps or the existence of some porosity induced by Sn aggregates.

To check the first hypothesis, the composite was washed with $\mathrm{HCl}$ to remove the $\mathrm{Sn} / \mathrm{SnO}_{2}$ particles followed by several analytical characterizations to confirm the efficiency of such treatment (Figure S4, Supporting Information). XRD pattern of the material after washing $(60 \% \mathrm{Sn} / \mathrm{C} @ \mathrm{HCl})$ reveals the absence of $\mathrm{Sn}$ peaks and the presence of specific phase of carbon with low degree of graphitization.

Table 4. Textural values of carbon support and $x \%$ Sn@C materials $(x=20 / 40 / 60 / 70 / 80)$

\begin{tabular}{cllll}
\hline Material & $\begin{array}{c}\text { BET SSA } \\
\mathrm{m}^{2} \mathrm{~g}^{-1}\end{array}$ & $\begin{array}{c}\mathrm{V}_{\mathrm{T}} \\
\mathrm{cm}^{3} \mathrm{~g}^{-1}\end{array}$ & $\begin{array}{c}\mathrm{V}_{\text {micro }} \\
\mathrm{cm}^{3} \mathrm{~g}^{-1}\end{array}$ & $\begin{array}{c}\mathrm{V}_{\text {meso }} \\
\mathrm{cm}^{3} \mathrm{~g}^{-1}\end{array}$ \\
\hline $\mathrm{C}$ & 665 & 0.97 & 0.28 & 0.69 \\
\hline 20\%Sn@C & 485 & 0.79 & 0.21 & 0.58 \\
40\%Sn@C & 404 & 0.66 & 0.17 & 0.49 \\
$60 \% S n @ C$ & 322 & 0.45 & 0.13 & 0.32 \\
$70 \% S n @ C$ & 249 & 0.28 & 0.12 & 0.16 \\
$80 \% S n @ \mathrm{C}$ & 181 & 0.17 & 0.07 & 0.11 \\
\hline
\end{tabular}

In addition, the TGA analysis in air indicates as well the complete removal of Sn-based nanoparticles since no $\mathrm{SnO}_{2}$ residue was observed after thermal treatment, the curve of $60 \% \mathrm{Sn} / \mathrm{C} @ \mathrm{HCl}$ is overlapped to that of carbon one. The $\mathrm{N}_{2}$ adsorption/desorption isotherms, present similar profiles to the pristine carbon support, suggesting that the carbon texture was not either modified by the synthesis procedure. Therefore, all these characterization point out that the carbon matrix texture, structure and thermal stability is not affected by the Sn nanoparticles synthesis procedure. However, for other metallic systems confined in microporous carbon, the modification of carbon porosity (specific surface area and pore size) could be observed due to the synthesis procedure [29].

The second hypothesis assumes some porosity coming from the small size of $\mathrm{Sn}$ particles or between the Sn-particles. The $\mathrm{Sn} / \mathrm{SnO}_{2}$ can be considered non-porous, with no intrinsic porosity. However, due to their nanometric size, the SSA may increase and an inter-particle porosity cannot be excluded as well. This porosity increases due to the fact that, by increasing the particle loading, more Sn particles are formed outside the carbon network and they may contribute to the SSA increase. In the same time, a part of particles can be confined in the pores of carbon leading to lower SSA and pore volume.
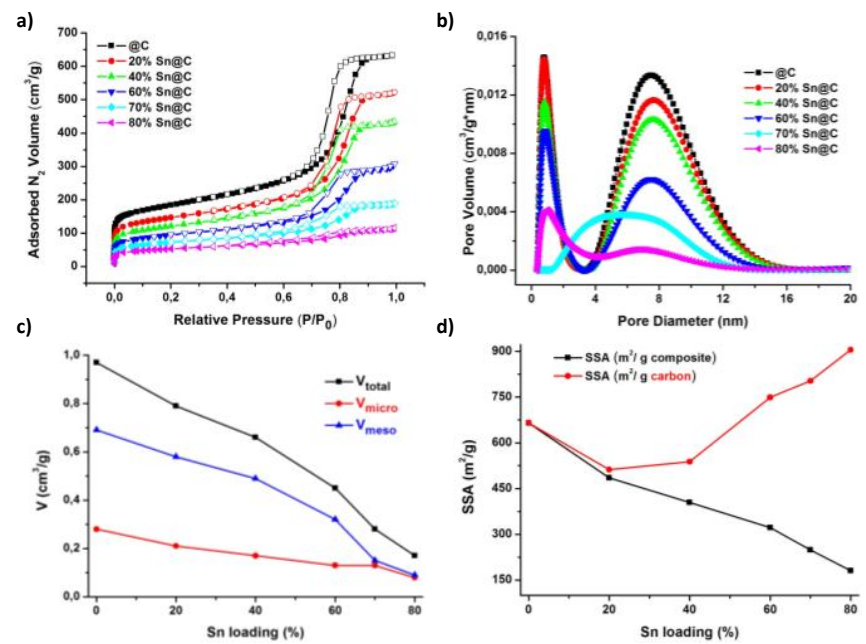

Figure 4. Textural properties for carbon and carbon/hybrid materials. $\mathrm{N}_{2}$ adsorption/desorption isotherms (77K) (a) and pore size distribution (b). The evolution of the porous volume (c) and SSA (d) with the Sn loading.

\section{Electrochemical performances}

From the physico-chemical analyses on the C/Sn-based materials, we observed that the modification of the Sn loading produces changes regarding the size and dispersion of the Snbased particles, their tendency to form agglomerates by increasing the $S n$ loading being highlighted. The Sn nanoparticles were found to be partially oxidized, and such oxide may play a role on the irreversible capacity. The textura properties such as SSA and porous volumes decreased with increasing of the Sn loading. All these characteristics may influence on the Li-ion batteries performances will be discussed in the following part.

The electrochemical tests for carbon and carbon/Sn-based materials were performed at constant $(\mathrm{C} / 5)$ and variable current rate (between $\mathrm{C} / 10$ and $3 \mathrm{C}$ ) in the voltage range of $0.01-1.5 \mathrm{~V}$ (vs $\mathrm{Li}^{\mathrm{Li}} \mathrm{Li}^{+}$. Figure 5 presents the galvanostatic and derivative curves for 60\%Sn@C for the specified cycles. The first discharge profile show a rapid voltage drop to $1.5 \mathrm{~V}$, followed by a gradually decrease down to $0.01 \mathrm{~V}$, delivering a discharge capacity of $1480 \mathrm{mAh} \mathrm{g}^{-1}$. The subsequent discharge curves are very different compared to the first one because of the formation of SEI on the surface of the anode during the first discharge. In the same time, the following curves are almost overlapped, indicating the good reversibility of the chemical reactions in the electrode and a good cycling stability. The initial charge capacity is $646 \mathrm{mAh} \mathrm{g}^{-1}$, corresponding to a coulombic efficiency of $89 \%$.

The derivative curves (Figure $5 \mathrm{~b}$ ) for the first discharge present three peaks badly defined at $0.63,0.0 .50$ and $0.38 \mathrm{~V}$, the first one being shifted to 0.42 starting for the second cycle. During charge three better defined derivative peaks are at 0.60 , 0.72 and $0.80 \mathrm{~V}$, in good agreement with those assigned to the reversible lithiation of $\mathrm{Sn}$ into $\mathrm{Li} \mathrm{Li}_{2} \mathrm{Sn}_{5}, \mathrm{LiSn}$ and $\mathrm{Li}_{2.5} \mathrm{Sn}$, respectively (Eq. 2) ${ }^{[2]}$. 

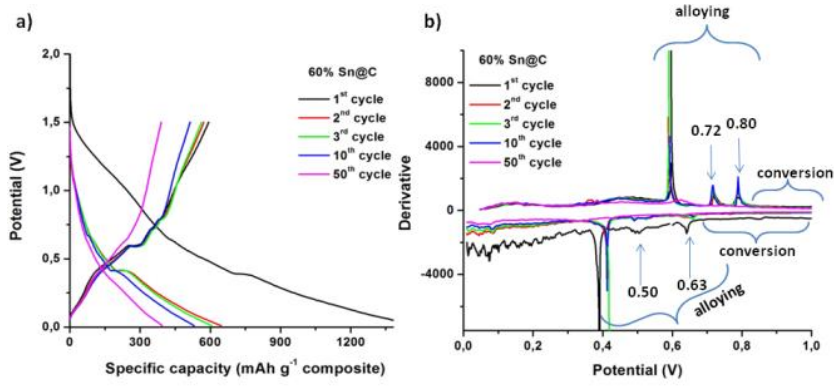

Figure 5. Galvanostatic (a) and derivative curves (b) for carbon/Sn composites 60\%Sn@C at C/5 current rate in the voltage range of 0.01-1.5 V (vs. Li/Li).

Note that no clear peak appears around $1 \mathrm{~V}$ in discharge which would have been ascribed to the conversion reaction (Eq. 1)

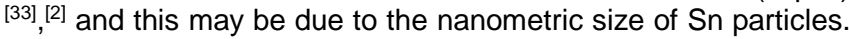
After 50 cycles the peaks are no more visible.

$$
\mathrm{SnO}_{2}+4 \mathrm{Li}^{+}+4 \mathrm{e}^{-} \rightarrow \mathrm{Sn}+2 \mathrm{Li}_{2} \mathrm{O}
$$

$$
\mathrm{Sn}+\mathrm{xLi}^{+}+\mathrm{xe}^{-} \leftrightarrow \mathrm{Li}_{\mathrm{x}} \mathrm{Sn}
$$

To evidence the contribution of the carbon support on the electrochemical results of $\mathrm{C} / \mathrm{Sn}$ hybrid materials, the carbon support, was tested in the same conditions as the composite materials (Figure 6). The reversible capacity of carbon support after 100 cycles was $204 \mathrm{mAh} \mathrm{g}^{-1}$, but a high irreversible capacity of $776 \mathrm{mAh} \mathrm{g}^{-1}$ was observed during the first chargedischarge cycle, representing $78 \%$ from the first charge capacity (Table S1a, Supporting Informations). The coulombic efficiency is quite low in the first cycle $(\approx 16 \%)$, but from the second one, it strongly increases to $80 \%$ and after 25 cycling reaching $100 \%$ (Figure 6a). The high irreversible capacity and the low columbic efficiency in the first cycles are related to the high surface area of carbon materials which induces the electrolyte decomposition with the formation of a solid electrolyte interphase.

The electrochemical performances of the hybrid materials were evaluated at constant and variable current rate and compared with their theoretical capacities (Figure 6). The theoretical capacity for each material was calculated by taking into account the real amount of each compound $\left(\mathrm{Sn} / \mathrm{SnO}_{2} / \mathrm{C}\right)$ (Table 2), with the theoretical capacities for $\mathrm{Sn}$ and $\mathrm{SnO}_{2}(990$ $\mathrm{mAh} \mathrm{g}^{-1}$ [5] and $781 \mathrm{mAh} \mathrm{g}^{-1}{ }^{[4]}$, respectively) and the experimental reversible capacity obtained for the carbon which was used as support.

The irreversible capacity of C@Sn composite materials is even higher than the carbon one, suggesting a contribution of Sn-based nanoparticles to the irreversible capacity (Figure 6b). In order to determine the impact of Sn-particles on the irreversible capacity, we calculated its contribution by taking into account the experimental irreversible capacities obtained for the carbons support.

As can be noticed a decrease of the irreversible capacity with the decrease of the carbon content in the C@Sn composites is clearly observed. The 20\%Sn@C presents an irreversible capacity of $1323 \mathrm{mAh} \mathrm{g}^{-1}$, from which $667 \mathrm{mAh} \mathrm{g}^{-1}$ due to the carbon while by increasing the Sn loading to $80 \%$, the irreversible capacity was reduced to $653 \mathrm{mAh} \mathrm{g}^{-1}$ (43\%). These values are lower than those of $\mathrm{Sn}$ powder, where an irreversible capacity around $1350 \mathrm{mAh} \mathrm{g}^{-1}$ representing 93\% from the initial capacity was reported in the literature [34]. The significant decrease of the irreversible capacity for $80 \% \mathrm{Sn} / \mathrm{C}$ compare to that of Sn powder (93\%) and, in the same time, to the irreversible capacity of the carbon support $(78 \%)$ indicates the importance of carbon matrix.

This decrease tendency of irreversible capacity may be related to the decrease of the specific surface area of the C@Sn materials, as demonstrated by the rather linear correlation of irreversible capacity with the specific surface area (Figure 6c). The presence of a smaller fraction of porous carbon limits the electrolyte decomposition and the solid electrolyte interphase (SEI) formation.
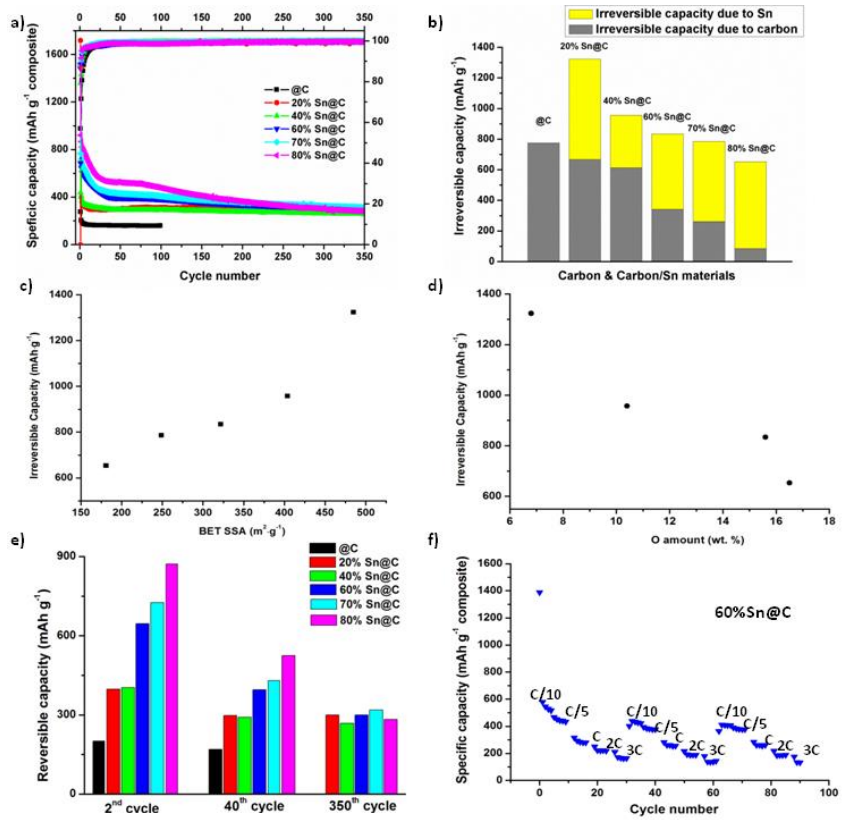

Figure 6. Specific discharge capacity and coulombic efficiency for the carbon and carbon/Sn materials as a function of cycle number at constant current rates $\mathrm{C} / 5 \mathrm{C}$ rate in the voltage range of $0.01-1.5 \mathrm{~V}\left(v s\right.$. $\left.\mathrm{Li}^{\prime} \mathrm{Li}^{+}\right)(\mathrm{a})$. The irreversible capacity after the first discharge (b). The correlation between the irreversible capacity and BET specific surface area (c) and oxygen amount in $\mathrm{Sn} / \mathrm{SnO}_{2}$ nanoparticles as determined by XPS (d); The reversible capacity after 2 cycles, 40 cycles and 350 cycles, respectively (e). Specific discharge capacity as a function of cycle number at variable current rates between $\mathrm{C} / 10$ and $3 \mathrm{C}(\mathrm{f})$.

Despite the strong decrease of irreversible capacity by decreasing the carbon fraction and the specific surface area, an important irreversible capacity is still coming from the $\mathrm{Sn}$ contribution. This is often assigned to the electrolyte consumption due to the conversion reaction of $\mathrm{SnO}_{2}$ into metallic $\mathrm{Sn}$ and $\mathrm{Li}_{2} \mathrm{O}$ (Eq. 1). If we represent the evolution of the irreversible capacity versus the oxygen amount in the $\mathrm{Sn} / \mathrm{SnO}_{2}$ particles (Figure 6d), one can be noticed that the irreversible capacity decreases with the increase of the oxygen amount in the materials, therefore, with the increase of the quantity of $\mathrm{SnO}_{2}$. At a first glance, this result seems rather unexpected since a higher amount of $\mathrm{SnO}_{2}$ in the composites is supposed to induce a higher irreversible capacity due to the reaction (1). However, some authors found also that the presence of $\mathrm{SnO}_{2}$ in $\mathrm{Sn} / \mathrm{SnO}_{2}$ materials is beneficial to limit the SEI formation, to improve the CE and also to provide long term cycling stability [35],[36], [37]. Therefore, the conversion reaction is not the only factor which may affect the irreversible capacity of $\mathrm{Sn} / \mathrm{SnO}_{2}$ materials. The electrolyte decomposition on the surface of small and reactive $\mathrm{Sn} / \mathrm{SnO}_{2}$ nanoparticles, with the formation of SEI layer or the modification of the particle size/morphology during $\mathrm{Li}^{+}$insertion may account as well for the observed irreversible capacity [38], [39], [35].

Concerning the reversible capacity (Figure 6e), this was also significantly improved by increasing the Sn loading from 397 mAh $\mathrm{g}^{-1}$ for 20 wt. $\% \mathrm{Sn}$ to $871 \mathrm{mAh} \mathrm{g}^{-1}$ for 80 wt.\% Sn, respectively. The values are even higher than the theoretical capacities for these materials (Table S1b, Supporting Information) due probably to some synergetic effects between the $\mathrm{Sn}$ nanoparticles and the carbon matrix. For high loadings $(60,70$ and $80 \mathrm{wt} . \%)$ after a drastically decrease of the capacity during the first 20 cycles $(\approx 40 \%)$, stable capacities of 524,430 , 
$326 \mathrm{mAh} \mathrm{g}^{-1}$ is maintained up to $80^{\text {th }}$ cycle, respectively. For lower Sn loadings, after the first cycles, the capacity is directly extremely low $\left(\sim 300 \mathrm{mAh} \mathrm{g}^{-1}\right)$, but not so far from the theoretical values (285 and 340 for 20 wt.\% Sn and $40 \%$ Sn respectively). Another decrease of the capacity occurs after 100 cycles for the higher loadings, which finally present almost the same capacity $\left(\approx 300 \mathrm{mAh} \mathrm{g}^{-1}\right)$ after 350 cycles (Figure 6e). The fading of capacity for the higher loadings could be a consequence of the large amount of agglomerated particles situated outside of the carbon pores, confirmed by STEM (Figure 2). These particles were not properly in contact with the conductive carbon network and non-confined as well in corbon pores to limit their volume expansion/strain during lithiation/delithiation. STEM analysis after cycling were performed for materials with 60 and $80 \mathrm{wt} . \%$ of $\mathrm{Sn}$ to see how the Sn-based particles were affected during the cycling (Figure 7). Compared to the materials before cycling (Figure 2b, c), the STEM images at this stage indicate that the 60\%Sn@C composite better conserves the particles size and dispersion (Figure 7a), while for 80\%Sn@C material the agglomerated particles are more present than before cycling (Figure $7 \mathrm{~b}$ ). These post-mortem investigations confirm that a moderate amount of $\mathrm{Sn}$ in the porous carbon frameworks is required to balance the particle aggregation, the material conductivity and electrolyte diffusion.

The evolution of the capacity for long cycling could indicate a similar maximal electrochemical potential no matter the Sn NPs loading. Therefore, to choose the most promising material which could be used as anode, we should consider the irreversible capacity, as well as the reversible capacity but not only during the first cycles which presents the highest value for the material with 80 wt.\% of $\mathrm{Sn}$, but also the long-term cycling stability behavior, which seems to be influenced, especially, by the dispersion of the particles in the carbon matrix.

The coulombic efficiency of the $\mathrm{C} / \mathrm{Sn}$ composite materials reaches fast $100 \%$ (after 10 cycles), which means that no parasitic reactions take place because of the electrolyte degradation is disappeared after first cycles.

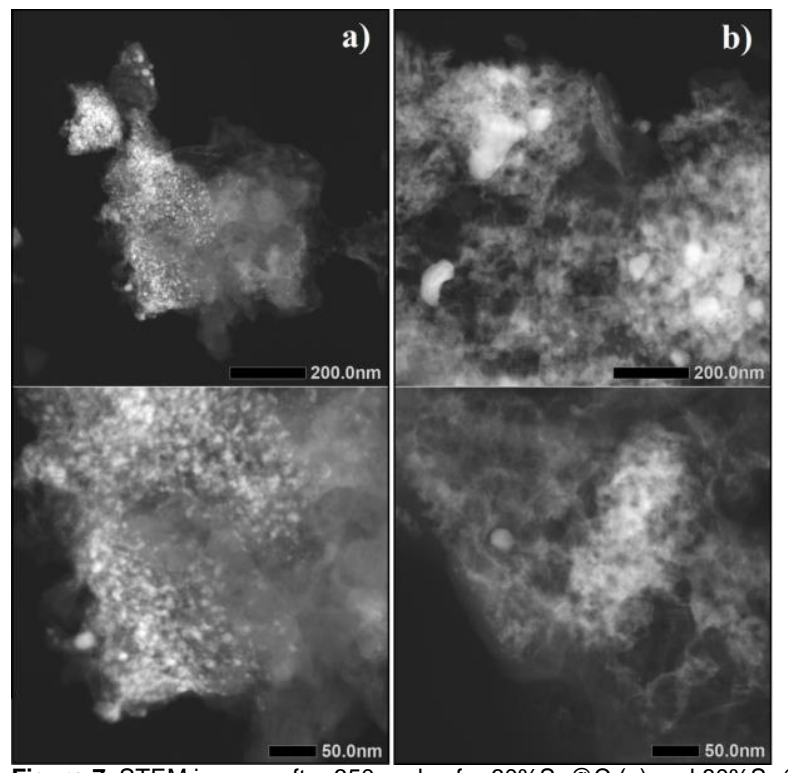

Figure 7. STEM images after 350 cycles for 60\%Sn@C (a) and $80 \%$ Sn@C (b).

Figure $6 f$ shows the cycling performances of the $\mathrm{C} / \mathrm{Sn}$-based materials at different current rates. The reversible discharge capacities of the composites strongly depend on the $\mathrm{C}$ rate and thus, for $\mathrm{Sn} / \mathrm{C}$ composite the values decrease to $578,466,314$, 249 and $210 \mathrm{mAh} \mathrm{g}^{-1}$ at $\mathrm{C} / 10, \mathrm{C} / 5, \mathrm{C}, 2 \mathrm{C}$ and $3 \mathrm{C}$, respectively, and successfully regain up to $90 \%$ from the initial capacity, when the current rate is set back to its initial value.

\section{Conclusions}

Mesoporous carbon/Sn-based materials with different Sn loading were prepared by a facile and fast route based on an impregnation/reduction bottom-up approach. For all loadings, a mixture of $\mathrm{Sn} / \mathrm{SnO}_{2}$ was formed and several complementary techniques (Mössbauer spectroscopy, XPS and TGA) were employed to carefully asses their amount and ratio in the carbon matrix to correctly evaluate their impact on the electrochemical performances. At low Sn loadings $(<60 \%)$ the Sn NPs are very homogenous dispersed in the carbon network with particle size around $5 \mathrm{~nm}$ and only few aggregates observed. The increase of the Sn loading induces the formation of larger Sn particles and many $\mathrm{Sn}$ agglomerates $(\sim 200 \mathrm{~nm})$, which are not embedded in the carbon porosity, as reveled by XRD and TEM. Moreover, the increase of the Sn loading in the carbon framework induces a significant decrease in the textural properties (SSA and pore volume) which could be assigned partly to the Sn density but also to the confinement of Sn particles into the carbon pores. It was evidenced also that the Sn nanoparticles may present a non negligible inter-grain porosity.

The increase of the Sn loading leads to a decrease of the irreversible capacity during the first cycle, which was mainly related to the decrease of the SSA. Improvement of the reversible capacity is achieved as well; however, the evolution of the reversible capacity for long cycling demonstrated significant fading for high loadings triggered by Sn NPs placed outside the carbon pores which undergo severe agglomeration due to volume expansion upon lithiation. Therefore, similar electrochemical performances are reached regardless the $\mathrm{Sn}$ NPs loading after 350 cycles. Our founding suggests that a high Sn loading combined to small and dispersed particle size in the carbon framework may be the key factor to achieve high reversible capacity and long term cycling.

\section{Experimental Section}

\section{Material synthesis}

The mesoporous carbon support was prepared by a softtemplate phase separation route as previously reported in our

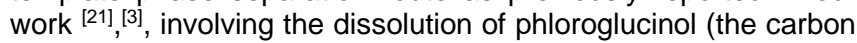
source, $1.65 \mathrm{~g}$ ) and Pluronic F-127 (pore generation agent, 3.27 g) in a solution of ethanol $(81 \mathrm{~mL})$ containing small quantity of hydrochloric acid $(0.6 \mathrm{~mL})$, followed by the glyoxal addition (1.62 $\mathrm{mL}$ ). The latter one is used as cross-linker to form a tridimensional phenolic resin with phloroglucinol able to selfassemble with the triblockpolymer template Pluronic F-127 via $\mathrm{H}$-bonding giving rise to mesophase nano-assemblies. Thermal annealing at $900^{\circ} \mathrm{C}$ of organic polymer phase allows to obtain the mesoporous carbon support.

The $\mathrm{C} / \mathrm{Sn}$ hybrid materials with different $\mathrm{Sn}$ loadings ( $\mathrm{x} \% \mathrm{Sn} @ \mathrm{C}$, where $x=20 / 40 / 60 / 70 / 80$ ) were prepared by liquid impregnation of the porous carbon network (C) with a $\mathrm{SnCl}_{4} \cdot 5 \mathrm{H}_{2} \mathrm{O}$ ethanol solution under stirring for $30 \mathrm{~min}$, followed by a chemical reduction process with $\mathrm{NaBH}_{4}$ solution in water in order to reduce the $\mathrm{SnCl}_{4} \cdot 5 \mathrm{H}_{2} \mathrm{O}$ to $\mathrm{Sn}\left(0.6 \mathrm{~g} \quad \mathrm{NaBH}_{4} / 1 \mathrm{~g}\right.$ $\mathrm{SnCl}_{4} \cdot 5 \mathrm{H}_{2} \mathrm{O}$ ). The reducing agent was eliminated by washing the material with distilled water at room temperature. The final material was dried at $80^{\circ} \mathrm{C}$ for $12 \mathrm{~h}$.

\section{Materials characterization}


The crystalline structure of the materials was characterized by X-ray powder diffraction (XRD) technique, by using a powder diffractometer D8 ADVANCE A25 from Bruker in BraggBrentano reflection geometry $\theta-\theta$. This diffractometer is equipped with the LynxEye XE-T high resolution energy

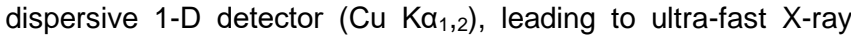
diffraction measurements. The X-ray powder diffraction data uses proprietary Bruker format which are converted into usable one via PowDLL $2.71^{[26]}$. The Sn crystallite size was determined using the Scherrer formula and the FWHM (Full Width at Half Maximum) was extracted via DIFFRAC.EVA [27] $\left(\mathrm{CuKa}_{2}\right.$ contribution previously removed) and also checked via WinPLOTR profile fitting procedure ${ }^{[40]}$. The material surface morphology/structure was investigated with a JEOL ARM-200F transmission electron microscope working at $200 \mathrm{kV}$. EDX mapping was obtained with a JED 2300 detector. Thermogravimetric analyses (TGA) were conducted on a TGA 851 (Mettler-Toledo) thermogravimeter by heating the samples under air $(100 \mathrm{ml} / \mathrm{min})$, from $30^{\circ} \mathrm{C}$ up to $900^{\circ} \mathrm{C}$ with a $10^{\circ} \mathrm{C} / \mathrm{min}$ heating rate.

${ }^{119} \mathrm{Sn}$ Mössbauer spectra were collected with a constant acceleration spectrometer using a $\mathrm{Ca}^{119 \mathrm{~m}} \mathrm{SnO}_{3}$ source in the transmission geometry. They were fit by combinations of Lorentzian lines. The absorber used for the determination of the hyperfine parameters contained $120 \mathrm{mg} \mathrm{cm}{ }^{2}$ of the $\mathrm{Sn}$ composite. The velocity scale is calibrated with a ${ }^{57} \mathrm{Co}$ source and a pure iron foil absorber. The isomer shifts are given relative to $\mathrm{BaSnO}_{3}$ standard at room temperature. The absorption areas were further used to calculate the quantities of $\mathrm{Sn}$ and $\mathrm{SnO}_{2}$ loaded in the carbon/Sn hybrid materials. Lamb-Mössbauer factors of 0.5 and 0.05 have been assumed for the conversion of absorption areas for $\mathrm{SnO}_{2}$ and $\mathrm{Sn}$, respectively [32]. X-ray photoelectron spectroscopy (XPS) was performed with a VG Scienta SES 200-2 spectrometer equipped with a monochromatized Al Ka X-ray source $(1486.6 \mathrm{eV})$ and a hemispherical analyzer. The pass energy was $100 \mathrm{eV}$.

The textural properties of the carbon and carbon/Sn hybrid materials were evaluated using $\mathrm{N}_{2}$ adsorption/ desorption isotherms measured with a Micromeritics ASAP 2420 device at $77 \mathrm{~K}$. The samples were out-gassed in vacuum at $80^{\circ} \mathrm{C}$ for $12 \mathrm{~h}$ before the adsorption analysis. The specific surface area (SSA) was calculated from the linear plot in the relative pressure range of 0.01-0.05. The micropore volume $\left(\mathrm{V}_{\text {micro, }}\right.$, pore size $\left.<2 \mathrm{~nm}\right)$ was obtained using the Dubinin-Radushkevich (DR) equation in the relative pressure interval $\left(P / P_{0}\right)$ from $10^{-4}$ to $10^{-2}$. The total pore volume $\left(\mathrm{V}_{T}\right)$ was determined from the amount of nitrogen adsorbed at a relative pressure of 0.95 . The mesoporous volume $\left(V_{\text {meso, }} 2 \mathrm{~nm}<\right.$ pore size $\left.<50 \mathrm{~nm}\right)$ was determined by subtracting the microporous volume form the total pore volume. The pore size distributions (PSD) were determined from the adsorption branch of nitrogen isotherms using the 2D NLDFT heterogeneous surface model for carbon materials implemented in SAIEUS (Micromeritics) ${ }^{[41]}$.

\section{Electrochemical characterization}

The electrode preparation was made by mixing in a jar the synthesized materials $(70 \%)$ with carbon black $(10 \%)$ and vapor grown carbon fibers - VGCF-S $(10 \%)$ as conductive additive, and carboxymethylcellulose - CMC (10\%) as binder. A quantity of $0.4 \mathrm{ml}$ distillated water was added over the materials and homogeneously mixed by ball-milling for $1 \mathrm{~h}$. The film with a thickness of $100 \mu \mathrm{m}$ was laid down on a copper foil, dried at room temperature for $4 \mathrm{~h}$ and at $100^{\circ} \mathrm{C}$ under vacuum for other $12 \mathrm{~h}$. The electrochemical results were calculated based on the active mass, which was considered the mass of the carbon $/ \mathrm{Sn} / \mathrm{SnO}_{2}$ composite. The corresponding loading of the active mass in the electrode was comprised between 0.9 and $1.9 \mathrm{mg} / \mathrm{cm}^{2}$.

The electrochemical performances of carbon and carbon/Snbased materials as negative electrode for Li-ion batteries were studied in coin cells assembled in an argon filled glove box. The electrolyte used for the coin cell preparation was $\mathrm{LiPF}_{6}$ with ethylene carbonate (EC), propylene carbonate (PC), dimethyl carbonate (DMC) (1:1:3) as solvents and vinyl carbonate (VC) $(1 \%)$ and fluoro ethylene carbonate (FEC) $(5 \%)$ as additives. The galvanostatic charge and discharge measurements were carried out at room temperature on Neware battery testing system (BTS3000) at room temperature. The capacity is reported per gram of $\mathrm{C} / \mathrm{S} n$ composite.

\section{Acknowledgements}

The authors gratefully acknowledge the financial support of this work from University of Haute-Alsace, France through the Ph.D. scholarship of Cristina Nita. We thank Loic Vidal and Samar Hajjar for STEM and XPS analyses performed via the IS2M Mulhouse technical platform.

Keywords: carbon/Sn hybrids; mesoporous carbon; tin-based nanoparticles; Li-ion batteries.

\section{References}

[1] J.-M. Tarascon, M. Armand, Nature 2001, 414, 359-367.

[2] H. Tavassol, M. W. Cason, R. Nuzzo, A. Gewirth, Adv Mater Lett 2011, 5, 1400317.

[3] A. Jahel, C. Matei Ghimbeu, L. Monconduit, L. Vix-Guterl, Adv.Energ.Mater. 2014, 4, 1400025

[4] F. Courtel, Abu-Lebdeh, in Nanotechnology for Lithium-Ion Batteries, Springer, Boston, MA 2012, 67-83.

[5] B. Wang, B. Luo, X. Li, L. Zhi, Mater Today 2012, 15, 544 552.

[6] C. Kim, M. Noh, M. Choi, J. Cho, B. Park, Chem Mater 2005 17, 3297-3301.

[7] G. Du, C. Zhong, P. Zhang, Z. Guo, Z. Chen, H. Liu Electrochem Acta 2010, 55, 2582-2586.

[8] Y. Zhong, X. Li, R. Zhang, R. Li, M. Cai, X. Sun, Appl Surface Science 2015, 332, 192-197.

[9] X. Bai, B. Wang, H. Wang, J. Jiang, J Alloys Compd 2015, 628,412

[10] G. Guo, Q. Yang, J. Liang, L. Wang, Y. Zhu, Y. Qian, Mater Lett 2016, 184, 332-335.

[11] S. Liang, X. Zhu, P. Lian, W. Yang, H. Wang, J Solid State Chem 2011, 184, 1400-1404.

[12] B. Veeraraghavan, A. Durairajan, B. Haran, B. Popov, R Guidotti, J Electrochem Soc 2002, 2002, 675-681.

[13] Y. Xu, Y. Zhu, Y. Liu, C. Wang, Adv Energy Mater 2013, 3 , 128-133.

[14] C. Liu, H. Huang, G. Cao, F. Xue, R. Paredes Camacho, X. dong, Electrochimica Acta 2014, 144, 376-382.

[15] M. Wu, C. Wang, J. Chen, F. Wang, B. Yi, lonics 2013, 19 1341-1347.

[16] S. Han, J. Xu, B. Li, G. Liu, G. Song, Z. Guo, Matter Lett 2017, 199, 93-96.

[17] C. Cui, X. Liu, N. Wu, Y. Sun, Mater Lett 2015, 143, 35-37.

[18] P. Wu, N. Du, H. Zhang, J. Yu, Y. Qi, D. Yang, Nanoscale 2011, 3, 746-750.

[19] I. Meschini, F. Nobili, M. Manchini, R. Marassi, R. Tossici, A Savoini, M. Focarete, F. Croce, J Power Sources 2013, 226 241-248

[20] X. Liu, X. Li, J. Yu, Y. Sun, Matter Lett 2018, 223, 203-206.

[21] A. Jahel, C. Matei Ghimbeu, A. Darwiche, L. Vidal, S. HajiarGarreau, C. Vix-Guterl, L. Monconduit, J Mater Chem A 2015, 3, 11960-11969.

[22] Y. Wang, Z. Ma, C. Lu, Composite Interfaces 2016, 23, 273280.

[23] J. Ren, J. Yang, A. Abouimrane, D. Wang, K. Amine, J Power Sources 2011, 196, 8701-8705.

[24] X. Chang, T. Wang, Z. Liu, X. Zheng, J. Zheng, X. Li, Nano Res 2017, 10, 1950-1958. 
[25] C. Matei Ghimbeu, C. Zlotea, R. Gadiou, F. Cuevas, E. Leroy, M. Latroche, C. Vix-Guterl, J.Mater.Chem. 2011, 21, 17765-17775.

[26] N. Kourhoumelis, ICDD Annu.Spring Meet.Ed Lisa ONeill Powder Diffr. 2013, 28, 137-148.

[27] P. Caussin, J. Nusinovici, D. W. Beard, Adv.X-ray Anal. 1988, 31, 423-430.

[28] P. Scherrer, Gött.Nachr. 1918, 2, 98-100.

[29] C. Zlotea, Y. Oumellal, S.-J. Hwang, C. Matei-Ghimbeu, P. Jongh, M. Latroche, J Phys Chem C 2015, 119, 1809118098.

[30] S. Sun, C. Matei Ghimbeu, Vix-Guterl-C, M.-T. Sougrati, C. Masquelier, R. Janot, J Power Sources 2015, 284, 574-581.

[31] E. Sutter, F. Ivars-Barcelo, P. Sutter, Part.Part.Syst.Charact. 2014, 31, 879-885.

[32] M. Sourgati, S. Jouen, B. Hannoyer, Hyperfine Interact 2006, 167, 815-818.

[33] S. Böhme, B. Philippe, K. Edström, L. Nyholm, J Phys Chem C 2017, 121, 4924-4936.

[34] G. Wang, B. Wang, X. Wang, J. Park, S. Dou, H. Ahnb, K. Kimb, J Mater Chem 2009, 19, 8378-8384.

[35] M. Inaba, T. Uno, A. Tasala, J Power Sources 2005, 146, 473-477.

[36] K. Chiu, H. Lin, K. Lin, J Electrochem Soc 2006, 2006 , A1038-A1042.

[37] A. Sivashanmugam, T. Kumar, N. Renganathan, S. Gopukumar, Wohlfahrt-Mehrens, J. Garche, J Power Sources 2005, 144, 197-203.

[38] R. Hu, H. Liu, M. Zeng, J. Liu, Chin Sci Bull 2012, 57, 41194130.

[39] S. Beattie, T. Hatchard, A. Bonakdarpour, K. Hewitt, J. Dhan, $J$ Electrochem Soc 2003, 150, A701-A705.

[40] T. Roisnel, J. Rodriguez-Carvajal, Materials Science Forum, Proceedings of the Seventh European Powder Diffraction Conference (EPDIC 7) 2000, Ed. R. Delhez and E.J. Mittenmeijer, 2000, 118-123.

[41] J. Jagiello, J. Olivier, Carbon 2013, 55, 70-80. 


\section{Table of Contents}

Understanding the Sn loading impact on the performances of mesoporous carbon/Sn based nanocomposites in Li-ion batteries

Cristina Nita ${ }^{[a],[b]}$, Julien Fullenwarth ${ }^{[c],[d]}$, Laure Monconduit ${ }^{[c],[d]}$, Jean-Marc Le Meins ${ }^{[a]}$, Julien Parmentier ${ }^{[a]}$, Moulay Sougrati $[c],[d]$, Camélia Matei Ghimbeu [a],[d],*

Page No. - Page No.

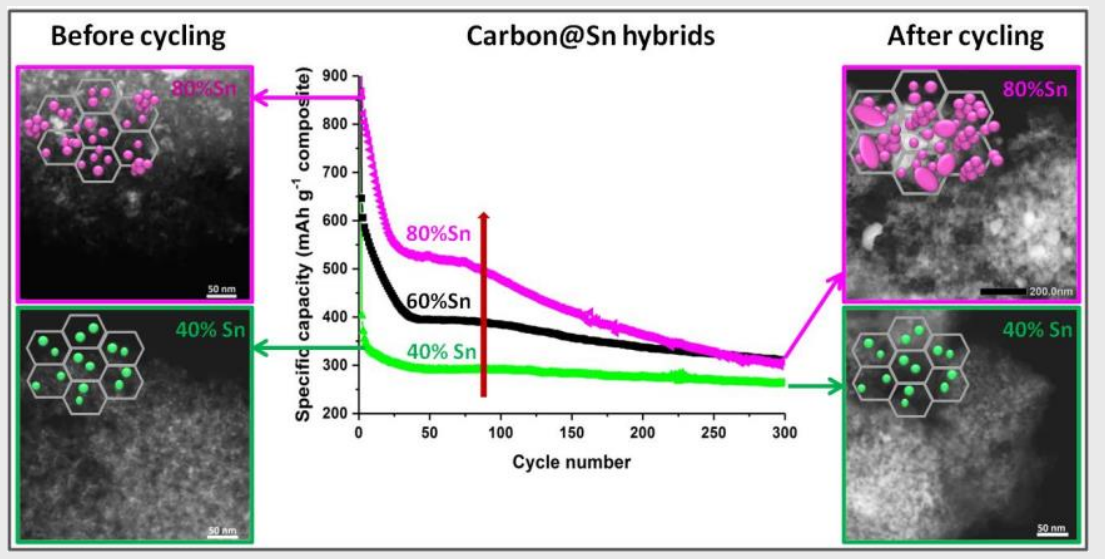

Sn loading affects the size and dispersion of Sn nanoparticles and is the key parameter to ensure long term battery cycling performances. 